\title{
Economic Evaluation of Rainwater Harvesting and Conservation (RWHC) Technologies for Sweet Potato Cultivation in Sierra Leone
}

\author{
Patrick Andrew Sawyerr ${ }^{1,}$,, Osman Nabay ${ }^{2}$, Keiwoma Mark Yila ${ }^{2}$ \\ ${ }^{1}$ Department of Soil Science, School of Agriculture, Njala University, Njala, Sierra Leone \\ ${ }^{2}$ Sierra Leone Agricultural Research Centre, Njala Agricultural Research Centre, Njala, Sierra Leone \\ Email address: \\ psawyerr@njala.edu.sl(P.A. Sawyerr),nabayosman@yahoo.com(O. Nabay),km_yila@yahoo.co.uk(K. M. Yila) \\ ${ }^{*}$ Corresponding author
}

\section{To cite this article:}

Patrick Andrew Sawyerr, Osman Nabay, Keiwoma Mark Yila. Economic Evaluation of Rainwater Harvesting and Conservation (RWHC) Technologies for Sweet Potato Cultivation in Sierra Leone. International Journal of Agricultural Economics. Vol. 4, No. 3, 2019 , pp. 94-100. doi: $10.11648 /$ j.ijae.20190403.12

Received: March 7, 2019; Accepted: April 26, 2019; Published: May 29, 2019

\begin{abstract}
A field trial was conducted to evaluate the economic performance of rainwater harvesting and conservation (RWHC) technologies for sweet potato cultivation in Sierra Leone during five intensive cropping seasons (2014 second - 2016 second cropping season) at the on-station research site of the Njala Agricultural Research Centre. The experiment was laid out in a randomized complete block design in three replications following a factorial combination of two levels of mulch (no mulch and mulch) and three levels of RWH structures (open ridge, tied ridge and arch ridge). Six RWHC technologies evaluated: open ridge without mulch (OR-M), open ridge with mulch $(\mathrm{OR}+\mathrm{M})$, tied ridge without mulch (TR-M) and tied ridge with mulch (TR+M), arch ridge without mulch (AR-M) and arch ridge with mulch (AR+M). Profitability (gross margin, net income and breakeven), investment (NPV, IRR and BCR) and sensitivity analyses (25\% root yield loss and $10 \%$ fall in the market price of sweet potato roots) were used to evaluate the economic performance of the RWHC techniques. The TR+M (SLL 2,091,280) had the highest net income followed by the AR-M (SLL 693,640) and AR+M (SLL 2,218,160) RWHC technologies. The traditional OR-M was not profitable (SLL $2,487,760$ ) for sweet potato cultivation. Based on the cost of production, the OR-M, OR+M, and TR-M RWHC technologies require a root yield increase of $50.5 \%, 3.0 \%$ and $35.4 \%$ to breakeven. The $\mathrm{AR}+\mathrm{M}$ had the highest and positive net seasonal cash flow returns throughout the five cropping seasons. The breakeven point on the net season seasonal cash flow returns for the TR+M, AR-M and OR+M RWHC technologies was in the 2015 main cropping season. At discount rates of $10 \%, 15 \%, 20 \%$ and $25 \%$ the highest NPV was obtained from the AR+M followed by the TR+M and AR-M RWHC technologies. The highest IRR was obtained from the AR+M (111\%) followed by TR+M (84\%) and AR-M (61\%). The AR+M, TR+M and AR-M RWHC technologies had benefit-cost ratios greater than 1 . Under uncertain conditions of $25 \%$ root yield loss and $10 \%$ fall in the market price of sweet potato roots, the $\mathrm{AR}+\mathrm{M}$ and $\mathrm{TR}+\mathrm{M}$ are the most profitable RWHC technologies that could be invested in. These technologies should, therefore, be promoted for adoption through on-farm trials in order to enhance intensive sweet potato cultivation on upland gravelly soils in Sierra Leone.
\end{abstract}

Keywords: Rainwater Harvesting and Conservation Technology, Profitability, Sweet Potato Productivity, Investment Analysis and Sensitivity Analysis

\section{Introduction}

Crop production under rain-fed conditions in Sub-Saharan Africa is highly constrained by variable rainfall, frequent droughts and low water productivity [1]. The amount of rainfall and the total water stored in the soil profile are two critical factors that determine the amount of water available for crop growth and for evapotranspiration [2]. The frequent occurrences of long intra-seasonal dry spells have the potential to cause a dramatic reduction in crop yields, thus threatening food security and the overall livelihood of the smallholder farmer [1]. Therefore, there is an urgent need to 
adopt climate-smart technologies that would increase the quantity of water required for crop growth in regions where rainfall amounts are low and erratic [2-3]. Sierra Leone falls within the humid tropics, with an average annual rainfall of about $2500 \mathrm{~mm}$. However, a very large amount of in-field rainwater is lost through evaporation and runoff. Water harvesting can reduce these losses, and alleviate waterrelated stress in agriculture [2-4]. Therefore, many countries in arid and semi-arid regions have focused their attention on developing and promoting efficient rainwater harvesting and conservation techniques that would enhance crop productivity on smallholder farms.

Sweet potato (Ipomoea batatas [L.] Lam) is a short duration crop that is widely grown throughout the year for its tubers and leaves mainly by smallholder farmers and is the third most important food crop after rice and cassava in Sierra Leone. In recent years, the crop has gained more dietary importance due to its potential to improve human nutrition, particularly children, through the $\beta$ - carotene content (a precursor of vitamin A) of orange flesh varieties [5]. Its widespread propagation every year depends on the quantity of vines that are harvested in the second cropping season and multiplied in swamps during the dry season. The vines harvest from the swamps serves as planting material for the first cropping season in May. Therefore, any factor that affects the second season sweet potato cultivation will have serious implications on the sustainability of sweet potato production in the country. Sweet potato cultivation during the second cropping season is constrained by low and erratic rainfall with intermittent rainless periods lasting up to seven days causing drastic yield reduction and drying of vines in the field before multiplication in the inland valley swamp (IVS).

Despite this challenge, there is strong evidence that rainwater harvesting has enhanced crop productivity in arid and semi-arid regions [6-7]. In-field rainwater harvesting has been proven to enhance crop growth and yield by increasing soil water content in areas with low and erratic rainfall [2]. In Sierra Leone, the current scientific research is focused on efforts to develop and test a wide variety of rainwater harvesting and conserving techniques for improving sweet potato productivity on low water retaining soils within the Njala area. The implementation of such rainwater harvesting and conservation technologies requires considerable capital investments for the purchase of tools, equipment and labour. The construction of rainwater harvesting and conservation structures is normally labour intensive and may often require communal or hired labour which is very expensive. Therefore, the economic evaluation of the rainwater harvesting and conservation technologies becomes an important aspect of the evaluation process and vary from simple farm budgeting techniques to more sophisticated investment and risk analysis. In this regard, this study was designed to evaluate the economic performance i.e. profitability, investment and sensitivity analysis of rainwater harvesting and conservation technologies that have been proven to increase sweet potato production in Sierra Leone.

\section{Materials and Methods}

\subsection{Experimental Sites}

The field experiments were located at Njala ( $\mathrm{N} 8^{\circ} 07^{\prime}$ and $\left.\mathrm{W} 12^{\circ} 05^{\prime}\right)$ in the southern province of Sierra Leone. The experimental site was located on a landscape ranging in slope from 5 to 9 degrees slope. Over time, erosion has selectively removed fine materials and left an accumulation of gravel on the soil surface, thereby increasing the proportion of this undesirable material to up to $90 \%$ by volume in the upper arable layer, reducing the water holding capacity of the soil.

\subsection{Design of Experiments and Treatments}

The experiment was a $2 \times 3$ factorial combination of 2 levels water conservation method (mulch and no mulch) and three levels of in-situ water harvesting structures (open ridge, tied ridge and arch ridge) laid out in a randomized complete block design in three replications. The experimental treatments were six rainwater harvesting and conservation (RWHC) technologies: open ridge without mulch - the control (T1:OR-M), open ridge with mulch $(\mathrm{T} 2: \mathrm{OR}+\mathrm{M})$, Tied ridge without mulch (T3:TR-M), tied ridge with mulch (T4:TR+M) Arch ridge without mulch (T5:AR-M), and arch ridge with mulch $(\mathrm{T} 6: \mathrm{AR}+\mathrm{M})$. The plot size for each experimental plot was $96 \mathrm{~m}^{2}(12 \mathrm{~m} \mathrm{x} 8 \mathrm{~m})$.

\subsection{Earthworks for the Rainwater Harvesting Structures}

\subsubsection{Open Ridge}

The traditional open ridge is used by most farmers to cultivate sweet potato. The catchment to cropping area (C: $\mathrm{CA})$ ratio of the open ridge $1: 1$.

\subsubsection{Tied Ridge}

The tied ridge was adapted from the traditional open ridge. The furrows between the open ridge structures were blocked or tied with raised earth at their ends. The C: CA ratio of a tied ridge was $1: 1$.

\subsubsection{Arch Ridge}

The Arch ridge was an innovative outcome adapted from the moon ridge historically designed for harvesting rainwater in the Sahel regions. The catchment to cropping area ratio was $1: 3$.

\subsection{Management Practices}

The field experiments were conducted under rain-fed conditions under five intensive cropping seasons (2014 second - 2016 second cropping season). The sweet potato cultivar used for the experiment was Kabia. Chicken manure was applied as basal at the rate of $5 \mathrm{t} \mathrm{ha}^{-1}$, two weeks before planting during the 2014 second cropping season. Organic mulch (Anthropogon macrophylum) was applied at the start of each cropping season at the rate of $6.7 \mathrm{t} \mathrm{ha}^{-1}$. The treatment plots with open and tied ridges were planted at the rate of 33,333 plants ha ${ }^{-1}$. The arch ridge treatment plots were planted at the rate of 22,222 plants $\mathrm{ha}^{-1}$. The plots were kept weed-free 
by hand weeding and harvested at 90 days after planting.

\subsection{Determination of Profitability Indicators}

\subsubsection{Gross Margin (SLL ha $\mathrm{ha}^{-1}$ )}

Gross margin was determined by subtracting the variable cost from the gross income. The gross income was estimated by multiplying the fresh root yield of sweet potato $(50 \mathrm{~kg}$ bags $\mathrm{ha}^{-1}$ ) by the farm gate price (SLL) of a $50 \mathrm{~kg}$ bag of fresh roots. The total variable cost (SLL ha $\left.{ }^{-1}\right)$ was estimated by adding up the cost of farm labour (land preparation, mulching weeding, harvesting and bagging) and planting material (sweet potato vines) for cultivating one hectare. Farm labour was rated at SLL 15,000 per man-day ( 8 hours of work) multiplied by the estimated number of man-days per hectare for each activity.

\subsubsection{Net Income (SLL ha-1)}

The net income was determined by subtracting the total fixed cost from the gross income. The total fixed cost (SLL $\mathrm{ha}^{-1}$ ) was determined by adding the land lease, depreciation of tools (pickaxe, machete, shovel, hoe, mattocks and garden lines), labour for earthworks and chicken manure required for cultivating one hectare. Depreciation cost for each farm tool was calculated as follows:

$$
\text { Depreciation }=\frac{\text { Cost of tools }- \text { Salvage value }}{\text { Number of useful years of the tools }}
$$

Where: Cost of tool $=$ the cost of the tool at the beginning of 2014 second cropping season; Salvage value is the value of the tool at the end of 2016 second cropping season; and Number of useful years of the tools $=2.5$ years.

\subsubsection{Breakeven Points}

The breakeven yield ( $50 \mathrm{~kg}$ bag $\mathrm{ha}^{-1}$ ) was determined by dividing the gross income by the farm gate price. The breakeven point in time (SLL) was determined by the net seasonal cash flow. It was calculated by subtracting the cumulative seasonal cash outflows from cumulative seasonal cash inflows.

\subsection{Determination of Investment Indicators}

The net present value (NPV) internal rate of return (IRR) and the benefit-cost ratio (BCR) were used to assess the investment potential of the RWHC technologies.

\subsubsection{Net Present Value (SLL)}

The NPV method consists of discounting all future cash flows to the present value by means of some appropriate rate of interest. It is based on the fundamental principle that the investment is worth undertaking only if the present value of the cash inflows is at least equal to, if not greater than, the present value of the cash outflows arising from an investment. In order words, investments should make investments in projects with a zero or positive net present value. The NPV was determined at different discount rates $(10 \%, 15 \% 20 \%$ and $25 \%$ ) and calculated as follows:

$$
\mathrm{NPV}=-\mathrm{C}_{\mathrm{o}}+\sum_{\mathrm{i}=1}^{\mathrm{T}} \frac{\mathrm{C}_{\mathrm{i}}}{(1+\mathrm{r})^{\mathrm{i}}}
$$

Where: $-\mathrm{C}_{0}=$ initial investment, $\mathrm{C}=$ cash flow, $\mathrm{r}=$ discount rate and $\mathrm{T}=$ time.

\subsubsection{Internal Rate of Return (IRR)}

The IRR is a discount rate that makes the net present value (NPV) of all cash flows from a particular project equal to zero. The IRR was calculated as follows:

$$
0=\mathrm{NPV}=\sum_{\mathrm{n}=1}^{\mathrm{N}} \frac{\mathrm{CFn}}{(1+\mathrm{IRR})^{\mathrm{n}}}
$$

Where: NPV $=$ Net present value, $\mathrm{n}=$ Each period, $\mathrm{N}=$ Holding period, $\mathrm{CF}=$ cash flow and $\mathrm{IRR}=$ Internal rate of returns.

\subsubsection{Benefit-Cost Ratio (BCR)}

The BCR is a financial ratio that compares the expected return (benefits) to the cost of investment. The BCR was determined by dividing the gross income by the total cost of production (total fixed cost + total variable cost).

\subsection{Sensitivity Analysis of the RWHC Technologies}

Since market dynamics change regularly, profit estimates may not be sufficient to measure the economic viability of an enterprise. Therefore, a more robust measure is required to determine the investment potential of the project. Therefore, sensitivity analysis on net seasonal cash flow and investment indicators (NPV, IRR and BCR) was conducted at 25\% yield loss for sweet potato production and $10 \%$ fall in farm gate price to test the resilience each of each RWHC technology during uncertainties.

\section{Results}

\subsection{Profitability}

\subsubsection{Gross Margin and Net Income}

Table 1 shows the average gross margins and net income obtained from the various RWHC technologies on sweet potato cultivation during five intensive cropping seasons (2014 second to 2016 second cropping season). The gross margin analysis showed that it is not profitable to cultivate sweet potato on the open ridge without mulch (OR-M) and tied ridge without mulch (TR-M). The highest gross margins were obtained from the tied ridge with mulch $(\mathrm{TR}+\mathrm{M})$ followed by the arch ridge with mulch $(\mathrm{AR}+\mathrm{M})$, arch ridge without mulch (AR-M) and open ridge with mulch $(\mathrm{OR}+\mathrm{M})$. Based on the net income analysis, the profitable RWHC technologies for the production of sweet potato roots were the TR+M (SLL 2,091,280), AR-M (SLL 693,640) and AR+M (SLL 2,218,160) RWHC technologies. The highest net income was obtained from the $\mathrm{AR}+\mathrm{M}$ ) followed by the $\mathrm{TR}+\mathrm{M}$ and $\mathrm{AR}-\mathrm{M}$. The highest net income obtained from the AR+M RWHC technology could be attributed to the lower total cost of production. The cropping area of the $\mathrm{AR}+\mathrm{M}$ technology was reduced by $33 \%$ for consequently the cost of farm inputs and labour reduced. For each technology, labour accounted for the highest cost. Similar results of high labour cost in sweet potato production under RWHC technologies have been reported in 
earlier research findings [8]. The high labour cost could be attributed to the high cost per man-day (SLL 15,000 per manday of 8 hours' work) and the number of man-days required to carry out land preparation, earthworks, acquisition of mulching materials, application of mulching materials, chicken manure, planting, weeding, harvesting and grading.

Table 1. Gross margin and net profit for the RWHC technologies.

\begin{tabular}{|c|c|c|c|c|c|c|}
\hline \multirow{2}{*}{ Items } & \multicolumn{6}{|c|}{ RWHC Techniques } \\
\hline & T1: OR-M & T2: OR+M & T3: TR-M & T4: TR+M & T5: AR-M & T6: $\mathbf{A R}+\mathrm{M}$ \\
\hline \multicolumn{7}{|l|}{ Gross Income } \\
\hline Average yield ( $50 \mathrm{~kg}$ bag ha $\left.{ }^{-1}\right)$ & 42.08 & 81.20 & 53.20 & 118.96 & 68.88 & 104.32 \\
\hline Sale Revenue (SLL ha-1) & $2,440,640$ & $4,709,600$ & $3,085,600$ & $6,899,680$ & $3,995,040$ & $6,050,560$ \\
\hline \multicolumn{7}{|l|}{ Variable Input Costs (SSL ha $\left.{ }^{-1}\right)$} \\
\hline Farm labour & $2,886,000$ & $2,814,000$ & $2,712,000$ & $2,742,000$ & $2,031,000$ & $2,562,000$ \\
\hline Total Variable Cost & $3,888,000$ & $3,816,000$ & $3,714,000$ & $3,744,000$ & $2,469,000$ & $3,000,000$ \\
\hline Gross Margin & $-1,447,360$ & 893,600 & $-628,400$ & $3,155,680$ & $1,526,040$ & $3,050,560$ \\
\hline \multicolumn{7}{|l|}{ Fixed Costs (SSL ha-1) } \\
\hline Land lease & 50,000 & 50,000 & 50,000 & 50,000 & 50,000 & 50,000 \\
\hline Depreciation on tools & 82,400 & 82,400 & 82,400 & 82,400 & 82,400 & 82,400 \\
\hline Earthworks & 426,000 & 426,000 & 450,000 & 450,000 & 486,000 & 486,000 \\
\hline Chicken manure & 482,000 & 482,000 & 482,000 & 482,000 & 214,000 & 214,000 \\
\hline Total Fixed Cost & $1,040,400$ & $1,040,400$ & $1,064,400$ & $1,064,400$ & 832,400 & 832,400 \\
\hline
\end{tabular}

Source: Field Data, 2014 second cropping season to 2016 second cropping season. Notes: Farm labour = cost for land preparation, mulching, weeding, harvesting and bagging. $\mathrm{OR}=$ open ridge, $\mathrm{TR}=$ tied ridge, $\mathrm{AR}=$ arch ridge and $\mathrm{M}=$ mulch

\subsubsection{Breakeven Points}

\section{Breakeven Yield}

Table 2 shows the actual and breakeven root yield of sweet potato cultivated under different rainwater harvesting and conservation technologies.

Table 2. Breakeven yield of sweet potato for the RWHC technologies (Average for 5 intensive cropping seasons).

\begin{tabular}{llll}
\hline \multirow{2}{*}{$\begin{array}{l}\text { RWHC } \\
\text { technologies }\end{array}$} & \multicolumn{2}{l}{ Yield (50 kg bag) } \\
\cline { 2 - 4 } Breakeven & Actual & Difference \\
\hline T1 :OR-M & 84.97 & 42.08 & 42.89 \\
T2 :OR+M & 83.73 & 81.2 & 2.53 \\
T3 :TR-M & 82.39 & 53.2 & 29.19 \\
T4 :TR+M & 82.90 & 118.96 & -36.06 \\
T5 :AR-M & 66.08 & 104.32 & -38.24 \\
T6 :AM+M & 56.92 & 68.88 & -11.96 \\
\hline
\end{tabular}

Source: Field Data, 2014 second cropping season to 2016 second cropping season. $\mathrm{OR}=$ open ridge, $\mathrm{TR}=$ tied ridge, $\mathrm{AR}=$ arch ridge and $\mathrm{M}=$ mulch

The actual root yield of sweet potato was lower than the breakeven root yield for OR-M, OR+M and TR-M RWHC technologies. To reach a breakeven point based on the total cost of production, the OR-M, OR+M, and TR-M RWHC technologies require a root yield increase of $50.5 \%, 3.0 \%$ and $35.4 \%$ respectively. The $\mathrm{TR}+\mathrm{M}, \mathrm{AR}-\mathrm{M}$ and $\mathrm{AR}+\mathrm{M}$ RWHC technologies attained root yield that surpasses the actual yield needed for breakeven by $43.5 \%, 57.9 \%$ and $21.5 \%$ respectively.

Net Seasonal Cash Flow

Table 3 shows the net seasonal cash flow streams for sweet potato production under different rainwater harvesting and conservation technologies. The net seasonal cash flows for OR-M and TR-M RWHC technologies was negative indicating no breakeven though out the five cropping seasons. The AR+M had the highest and positive net seasonal cash flow returns throughout the five cropping seasons. The breakeven point on the net season seasonal cash flow returns for the TR+M, AR-M and OR+M RWHC technologies was in the 2015 main cropping season. Except for the $A R+M$ technology, the other RWHC technologies had negative cash flows during the first cropping season (2014 second cropping season). The initial cost incurred in the 2014 cropping season was high when compared to the other cropping seasons for sweet potato production. This includes the fixed costs (land lease, earthworks, depreciation of tools and chicken manure) incurred in the 2014 cropping season. Similarly, a high initial investment cost for water harvesting systems have been reported in Tanzania [9]. For high economic returns, water harvesting systems should produce high yield and incur low production costs [10].

Table 3. Net seasonal cash flow streams (SLL) for sweet potato cultivation under different RWHC technologies.

\begin{tabular}{|c|c|c|c|c|c|}
\hline \multirow{2}{*}{ RWHC technologies } & \multicolumn{5}{|c|}{ Cropping Season } \\
\hline & 2014 second & 2015 main & 2015 second & 2016 main & 2016 second \\
\hline T1:OR-M & $-4,722,000$ & $-5,830,000$ & $-7,150,000$ & $-9,435,000$ & $-11,679,000$ \\
\hline $\mathrm{T} 2: \mathrm{OR}+\mathrm{M}$ & $-1,746,000$ & 32,000 & $1,424,000$ & 595,000 & 55,000 \\
\hline T3:TR-M & $-3,528,000$ & $-3,480,000$ & $-4,098,000$ & $-5,909,000$ & $-7,583,000$ \\
\hline $\mathrm{T} 4: \mathrm{TR}+\mathrm{M}$ & $-30,000$ & $3,862,000$ & $8,158,000$ & $9,575,000$ & $11,363,000$ \\
\hline T5:AR-M & $-289,000$ & $1,728,000$ & $3,837,000$ & $3,907,000$ & $4,564,000$ \\
\hline T6:AR+M & $1,376,000$ & $5,189,000$ & $10,319,000$ & $11,492,000$ & $12,152,000$ \\
\hline
\end{tabular}

Source: Field Data, 2014 second cropping season to 2016 second cropping season. $\mathrm{OR}=$ open ridge, $\mathrm{TR}=$ tied ridge, $\mathrm{AR}=$ arch ridge and $\mathrm{M}=$ mulch 


\subsection{Investment Potential of the RWHC Technologies}

Table 4 show analysis investment indicators for the different rainwater harvesting and conservation technologies for sweet potato production during five intensive cropping seasons. The $\mathrm{NPV}$, IRR and BCR are key indicators for evaluating the financial performance of rainwater harvesting investment projects [11-12].

\subsubsection{Net Present Value (NPV)}

The AR+M had the highest (SLL 12,170,800) total net income after five cropping seasons which was followed by the TR+M (SLL 11,356,400), AR-M (SLL 4,548,200) and $\mathrm{OR}+\mathrm{M}$ (SLL 4,600). The total net income for the OR-M and TR-M was negative. At a discount rate of $10 \%, 15 \%, 20 \%$ and $25 \%$, the $\mathrm{AR}+\mathrm{M}$ had the highest NPV which was followed by the TR+M and AR-M RWHC technologies. This shows that these RWHC technologies are worth investing in. The total net income for the TR-M and OR-M was negative indicating that these technologies were not worth investing in.

\subsubsection{Internal Rate of Return (IRR)}

The highest IRR that will make the NPV equal to zero was obtained from the AR+M (111\%) followed by TR+M $(84 \%)$ and AR-M (61\%). The IRR of these RWHC technologies is higher than the interest rate of $18 \%$ for a loan on agricultural investment from Community Banks in the country. The $\mathrm{OR}+\mathrm{M}$ had an IRR of $1 \%$ which was less than the interest rate of agricultural investment in the country. The OR-M and TR-M had negative cash flows.

\subsubsection{Benefit-Cost Ratio (BCR)}

The AR+M, TR+M and AR-M RWHC technologies had benefit-cost ratios greater than 1 . This shows that income generated from these technologies is greater than the cost of production, as such it is a profitable venture to invest in these RWHC technologies. The benefit-cost ratio for the OR-M, $\mathrm{OR}+\mathrm{M}$ and TR-M RWHC technologies was less than 1, indicating that these technologies are not worth investing in.

Table 4. Analysis of investment potential of the RWHC technologies during intensive five cropping seasons.

\begin{tabular}{|c|c|c|c|c|c|c|c|}
\hline \multirow{2}{*}{ RWHC Techniques } & \multirow{2}{*}{ Total Net Income (SLL) } & \multicolumn{4}{|l|}{ NPV } & \multirow{2}{*}{ IRR (\%) } & \multirow{2}{*}{ BCR } \\
\hline & & $10 \%$ & $15 \%$ & $20 \%$ & $25 \%$ & & \\
\hline T1:OR-M & $-11,679,000$ & $-8,687,453$ & $-7,661,495$ & $-6,840,912$ & $-6,174,568$ & - & 0.50 \\
\hline $\mathrm{T} 2: \mathrm{OR}+\mathrm{M}$ & 46,000 & $-341,397$ & $-502,449$ & $-640,437$ & $-757,665$ & 01 & 0.97 \\
\hline T3:TR-M & $-7,564,000$ & $-5,736,614$ & $-5,115,111$ & $-4,622,841$ & $-4,226,254$ & - & 0.65 \\
\hline $\mathrm{T} 4: \mathrm{TR}+\mathrm{M}$ & $11,356,400$ & $7,357,220$ & $5,968,572$ & $4,857,332$ & $3,958,662$ & 84 & 1.43 \\
\hline T5:AR-M & $4,548,200$ & $2,876,647$ & $2,282,789$ & $1,803,727$ & $1,413,637$ & 61 & 1.21 \\
\hline $\mathrm{T} 6: \mathrm{AR}+\mathrm{M}$ & $12,170,800$ & $8,351,995$ & $6,999,617$ & $5,900,491$ & $4,998,408$ & 111 & 1.58 \\
\hline
\end{tabular}

Source: Field Data, 2014 second cropping season to 2016 second cropping season. $\mathrm{OR}=$ open ridge, $\mathrm{TR}=$ tied ridge, $\mathrm{AR}=$ arch ridge and $\mathrm{M}=$ mulch

\subsection{Sensitivity Analysis}

\subsubsection{Net Seasonal Cash Flow}

Table 5 shows the net seasonal cash flow streams and breakeven points in the event of $25 \%$ yield loss for the rainwater harvesting and conservation technologies.

\section{$25 \%$ Root Yield Loss}

At $25 \%$ root yield loss of, the net seasonal cash flows for the OR-M, OR+M and TR-M technologies was negative indicating no breakeven though out the five cropping seasons. The AR+M had the highest and positive net seasonal cash flow returns starting 2015 main cropping season. The breakeven point on the net season seasonal cash flow returns for the TR+M occurred the 2015 second cropping season.

$10 \%$ Fall in the Market Price of Sweet Potato Roots

At $10 \%$ fall in the price of sweet potato roots, the net seasonal cash flows for the OR-M and TR-M technologies was negative indicating no breakeven though out the five cropping seasons. The $\mathrm{AR}+\mathrm{M}$ had the highest and positive net seasonal cash flow returns throughout the five cropping seasons. The breakeven point on the net season seasonal cash flow returns for the $\mathrm{TR}+\mathrm{M}$, AR-M and $\mathrm{OR}+\mathrm{M}$ with mulch technologies occurred during the 2015 main cropping season.

Table 5. Net seasonal cash flow streams (SLL) at 25\% yield loss and $10 \%$ fall in the price of sweet potato roots for RWHC technologies during five cropping seasons.

\begin{tabular}{|c|c|c|c|c|c|c|}
\hline \multirow{2}{*}{ Scenarios } & \multirow{2}{*}{ RWHC Techniques } & \multicolumn{5}{|c|}{ Cropping Season } \\
\hline & & 2014 second & 2015 main & 2015 second & 2016 main & 2016 second \\
\hline \multirow{6}{*}{$\begin{array}{l}25 \% \text { root yield } \\
\text { loss }\end{array}$} & T1:OR-M & $-5,580,000$ & $-7,441,500$ & $-9,364,500$ & $-12,108,750$ & $-14,724,750$ \\
\hline & $\mathrm{T} 2: \mathrm{OR}+\mathrm{M}$ & $-3,348,000$ & $-3,000,000$ & $-2,889,000$ & $-4,496,250$ & $-5,834,250$ \\
\hline & T3:TR-M & $-4,647,000$ & $-5,589,000$ & $-6,948,000$ & $-9,284,250$ & $-11,435,250$ \\
\hline & $\mathrm{T} 4: \mathrm{TR}+\mathrm{M}$ & $-2,046,000$ & $-90,000$ & $2,214,000$ & $2,313,750$ & $2,736,750$ \\
\hline & T5:AR-M & $-1,573,000$ & $-724,750$ & 271,250 & $-340,750$ & $-433,750$ \\
\hline & $\mathrm{T} 6: \mathrm{AR}+\mathrm{M}$ & $-403,000$ & $1,619,750$ & $4,847,750$ & $4,890,500$ & $4,593,500$ \\
\hline \multirow{6}{*}{$\begin{array}{l}10 \% \text { fall in market } \\
\text { price of sweet } \\
\text { potato roots }\end{array}$} & T1:OR-M & $-4,722,000$ & $-5,830,000$ & $-7,150,000$ & $-9,435,000$ & $-11,679,000$ \\
\hline & $\mathrm{T} 2: \mathrm{OR}+\mathrm{M}$ & $-1,746,000$ & 32,000 & $1,424,000$ & 595,000 & 55,000 \\
\hline & T3:TR-M & $-3,528,000$ & $-3,480,000$ & $-4,098,000$ & $-5,909,000$ & $-7,583,000$ \\
\hline & $\mathrm{T} 4: \mathrm{TR}+\mathrm{M}$ & $-30,000$ & $3,862,000$ & $8,158,000$ & $9,575,000$ & $11,363,000$ \\
\hline & T5:AR-M & $-289,000$ & $1,728,000$ & $3,837,000$ & $3,907,000$ & $4,564,000$ \\
\hline & $\mathrm{T} 6: \mathrm{AR}+\mathrm{M}$ & $1,376,000$ & $5,189,000$ & $10,319,000$ & $11,492,000$ & $12,152,000$ \\
\hline
\end{tabular}

Source: Field Data, 2014 second cropping season to 2016 second cropping season. $\mathrm{OR}=$ open ridge, $\mathrm{TR}=$ tied ridge, $\mathrm{AR}=$ arch ridge and $\mathrm{M}=$ mulch 


\subsubsection{Investment Potential of the RWHC Technologies}

Table 6 below shows the investment potential of the rainwater harvesting and conservation technologies of $25 \%$ yield loss and $10 \%$ fall in the price of the sweet potato roots.

25\% Root Yield Loss

After five cropping seasons, AR+M (SLL 4,607,600) had the highest total net income, followed by the TR+M (SLL 2,731,800). This show that these RWHC technologies are worthwhile investing. The total net income for the AR-M arch ridge without mulch, TR-M, OR-M, OR+M was negative indicating that these technologies were not worth investing in. At a discount rate of $10 \%, 15 \%, 20 \%$ and $25 \%$, the OR-M, OR+M, TR-M and AR+M had negative NPVs whilst the $\mathrm{AR}+\mathrm{M}$ and $\mathrm{TR}+\mathrm{M}$ had positive NPVs. The highest NPV was obtained from the AR+M followed by the TR+M.

At an NPV of 0 , the IRR for $\mathrm{AR}+\mathrm{M}$ and $\mathrm{TR}+\mathrm{M}$ was $50 \%$ and $26 \%$ respectively. These RWHC technologies had IRRs that are greater than the interest rate of $18 \%$ for an agricultural loan in the country. The AR-M had a negative IRR (-12\%) which shows the aggregate amount of cash flows caused by this technology was less than the amount of the initial investment, therefore, investment on this should not make take. The OR-M and TR-M had negative cash flows, therefore a number error occurred when calculating their IRR.

The benefit-cost ratio for the OR-M, OR+M, TR-M and
AR-M with was less than 1, indicating that these technologies are not worth investing in. The $\mathrm{AR}+\mathrm{M}$ and $\mathrm{TR}+\mathrm{M}$ technologies had benefit-cost ratios greater than 1 .

$10 \%$ Fall in the Market Price of Sweet Potato Roots

After five cropping seasons, AR+M (SLL 9,145,520) had the highest total net income, followed by the $\mathrm{TR}+\mathrm{M}$ (SLL7,906,560) and AR-M (SLL2,550,680). This shows that these RWHC technologies are worthwhile investing even if the market price of the roots falls by $10 \%$. The total net income for the TR-M, OR-M and OR+M was negative indicating that these technologies were not worth investing in. At a discount rate of $10 \%, 15 \%, 20 \%$ and $25 \%$, the OR-M, OR+M and $\mathrm{TR}+\mathrm{M}$ had negative NPVs whilst the $\mathrm{AR}+\mathrm{M}$, TR $+\mathrm{M}$ and $\mathrm{AR}-$ $M$ had positive NPVs. The highest NPV was obtained from the $\mathrm{AR}+\mathrm{M}$ followed by the $\mathrm{TR}+\mathrm{M}$ and $\mathrm{AR}-\mathrm{M}$ technologies.

At an NPV of 0 , the IRR for AR+M, TR+M and AR-M was $88 \% \quad 63 \%$ and $39 \%$ respectively indicating that these RWHC technologies had IRRs that are greater than the interest rate of $18 \%$ for an agricultural loan in the country. The OR-M, OR $+\mathrm{M}$ and TR-M had negative cash flows, therefore a number error occurred when calculating their IRR

The benefit-cost ratio for the OR-M, OR+M and TR-M less than 1 , indicating that these technologies are not worth investing in. The AR+M, TR+M and AR-M technologies had benefit-cost ratios greater than 1 .

Table 6. Analysis of investment potential of RWHC technologies $25 \%$ yield loss and $10 \%$ fall in the price of sweet potato roots for RWHC technologies during five cropping seasons.

\begin{tabular}{|c|c|c|c|c|c|c|c|c|}
\hline \multirow{2}{*}{ Scenarios } & \multirow{2}{*}{$\begin{array}{l}\text { RWHC } \\
\text { Techniques }\end{array}$} & \multirow{2}{*}{$\begin{array}{l}\text { Total Net Profit } \\
\text { (SLL) }\end{array}$} & \multicolumn{4}{|l|}{ NPV } & \multirow{2}{*}{ IRR (\%) } & \multirow{2}{*}{ BCR } \\
\hline & & & $10 \%$ & $15 \%$ & $20 \%$ & $25 \%$ & & \\
\hline \multirow{6}{*}{$25 \%$ root yield loss } & T1:OR-M & $-14,709,600$ & $-10,869,659$ & $-9,539,626$ & $-8,472,742$ & $-7,604,473$ & - & 0.38 \\
\hline & $\mathrm{T} 2: \mathrm{OR}+\mathrm{M}$ & $-5,841,000$ & $-4,548,367$ & $-4,118,380$ & $-3,778,259$ & $-3,504,011$ & - & 0.75 \\
\hline & T3:TR-M & $-11,421,000$ & $-8,506,715$ & $-7,503,208$ & $-6,701,023$ & $-6,049,965$ & - & 0.50 \\
\hline & $\mathrm{T} 4: \mathrm{TR}+\mathrm{M}$ & $2,731,800$ & $1,287,580$ & 787,269 & 389,805 & 71,803 & 26 & 1.12 \\
\hline & T5:AR-M & $-455,600$ & $-669,626$ & $-756,253$ & $-826,302$ & $-882,494$ & -12 & 0.97 \\
\hline & $\mathrm{T} 6: \mathrm{AR}+\mathrm{M}$ & $4,607,600$ & $2,995,616$ & $2,414,172$ & $1,937,085$ & $1,542,948$ & 0.50 & 1.25 \\
\hline \multirow{6}{*}{$\begin{array}{l}10 \% \text { fall in market } \\
\text { price of sweet } \\
\text { potato roots }\end{array}$} & T1:OR-M & $-12,879,120$ & $-9,560,336$ & $-8,412,747$ & $-7,493,644$ & $-6,746,530$ & - & 0.46 \\
\hline & $\mathrm{T} 2: \mathrm{OR}+\mathrm{M}$ & $-2,308,800$ & $-2,024,185$ & $-1,948,822$ & $-1,895,566$ & $-1,856,203$ & - & 0.90 \\
\hline & T3:TR-M & $-9,106,800$ & $-6,844,655$ & $-6,070,350$ & $-5,454,114$ & $-4,955,738$ & - & 0.60 \\
\hline & $\mathrm{T} 4: \mathrm{TR}+\mathrm{M}$ & $7,906,560$ & $4,929,364$ & $3,896,051$ & $3,070,321$ & $2,403,918$ & 0.63 & 1.34 \\
\hline & T5:AR-M & $2,550,680$ & $1,458,138$ & $1,067,172$ & 751,715 & 495,184 & 0.39 & 1.17 \\
\hline & T6:AR+M & $9,145,520$ & $6,209,444$ & $5,165,439$ & $4,315,128$ & $3,616,224$ & 0.88 & 1.51 \\
\hline
\end{tabular}

Source: Field Data, 2014 second cropping season to 2016 second cropping season. $\mathrm{OR}=$ open ridge, $\mathrm{TR}=$ tied ridge, $\mathrm{AR}=$ arch ridge and $\mathrm{M}=$ mulch

\section{Conclusions}

The most profitable RWHC technologies for sweet potato production on sloping upland soils with high gravel content and low water holding capacity are technologies that have the potential to reduce the cost of production and increase the fresh root yield. The cost of farm inputs and labour for cultivating sweet potato on the arch ridge was lower due to the reduction of the cropping area by $33 \%$. Rainwater harvesting structures with mulch had higher fresh root yields than those without mulch, thus generating higher revenues. The $\mathrm{AR}+\mathrm{M}, \mathrm{TR}+\mathrm{M}$ and $\mathrm{AR}-\mathrm{M}$ are profitable $\mathrm{RWHC}$ technologies with for sweet potato production on sloping upland soils with high gravel content and low water holding capacity are technologies. These technologies had a positive net income. The traditional OR-M technology was not profitable even during the $1^{\text {st }}$ cropping season (2014 second cropping season). The NPV, IRR and BCR are key indicators for evaluating the investment potential of rainwater harvesting investment projects. At a discount rate of $10 \%$, $15 \%, 20 \%$ and $25 \%$, the NPV for the AR+M, TR+M and AR-M RWHC technologies were positive. These RWHC technologies had IRR greater than the interest rate of $18 \%$ for an agricultural investment loan from Community Banks and BCR was also greater the one (1). Therefore, the RWHC technologies that could be invested in are the $A R+M, T R+M$ and AR-M. However, under uncertain conditions that could reduce the fresh root yield by $25 \%$, the $\mathrm{AR}+\mathrm{M}$ and $\mathrm{TR}+\mathrm{M}$ are the profitable RWHC technologies that sweet potato 
farmers could invest in. The total net income and NPV were positive, the IRR greater than the interest rate for an agricultural investment loan from community banks and BCR greater than one (1).

The most profitable RWHC technologies that could be invested in under intensive crop production systems on sloping upland gravelly soil and uncertain conditions of low fresh root yield of sweet potato are the $\mathrm{TR}+\mathrm{M}$ and $\mathrm{AR}+\mathrm{M}$ arch RWHC technologies. For intensive sweet potato production on upland gravelly soil, the $\mathrm{TR}+\mathrm{M}$ and $\mathrm{AR}+\mathrm{M}$ should be promoted for adoption through on-farm trials within the country.

\section{Acknowledgements}

This research was funded by the Sierra Leone Agricultural Research Institute (SLARI) and a loan from the Sierra Leone Commercial (SLCB) and Taiama Community Banks (TCB). The authors also express appreciation to the technical staff of the Njala Agricultural Research Centre for providing laboratory and field support to this study.

\section{References}

[1] Barros, V. R., Field, C. B., Dokken, D. J., Mastrandrea, M. D., Mach, K. J., Bilir, T. E., Chatterjee, M., Ebi , K. L., Estrada, Y O., Genova, R. C., Girma, B., Kissel, E. S, Levy, A. N., MacCracken, S., Mastrandrea, P. R., White, L. L., Niang, I., Ruppeln, O. C., Abdrabo, M. A., Essel , A., Lennard , C., Padgham, J., \& Urquhart, P. (2014). Africa, climate change 2014: impacts, adaptation, and vulnerability. Part B: regional aspects. Contribution of working group II to the fifth assessment report of the intergovernmental panel on climate change. Cambridge University Press, Cambridge, pp 1199 1265 .

[2] Critchley, W. \& Gowing, J. (2012). Water harvesting in SubSaharan Africa Routledge 2 Park Square, Milton Park, Abingdon, Oxon OX14 4RN.
[3] Lal, R. \& Stewart, B. A. 2013. Principles of Sustainable soil management in agroecosystems. Advances in Soil Science. CRC Press. Taylor and Francis Group. Boca Raton. London, New York.

[4] Oweis, T., \& Hachum , A. 2009. Water harvesting for improved rainfed agriculture in the dry environments. Integrated Water and Land Management Program, International Center for Agricultural Research in the Dry Areas ICARDA), Aleppo, Syria.

[5] Nedunchezhiyan, M., Byju, G. \& Jata, S. K. (2012). Sweet Potato Agronomy. Fruit, Vegetable and Cereal Science and Biotechnology. Global Science Book.

[6] Oweis, T., Hachum, A. \& Bruggeman, A. (eds) 2004. Indigenous Water Harvesting Systems in West Asia and North Africa, ICARDA, Aleppo, Syria.

[7] Rockstrom, J., Barron, J., Fox, P. (2002). Rainwater management for increased productivity among smallholder farmers in drought-prone environments. Physics and Chemistry of the Earth. 27, 949-959.

[8] Kassali, R. (2011). Economics of Sweet Potato Production. International Journal of Vegetable Science. Vol 17, 2011, Issue 4 Pages 313-321.

[9] Hatibu, N., Mutabazi, K., Senkondo, E. M. \& Msangi, A. S. K (2006). Economics of rainwater harvesting for crop enterprises in the semi-arid areas of East Africa. Agricultural Water Management 80,74-86.

[10] Yuan, T., Fengmin, L. \& Puhai, L. (2003). Economic analysis of rainwater harvesting and irrigation methods, with an example from China. Agricultural Water Management 60 217-226.

[11] Kunze, D., 2000: Economic Assessment of Water Harvesting Techniques: A demonstration of Various Methods. - Quarterly Journal of International Agriculture 39 (1): 69-91.

[12] Senkondo, E. M. M., Msangi, A. S. K., Xavery, P., Lazaro, E. A. and Hatibu, N. (2004). Profitability of Rainwater Harvesting for Agricultural Production in Selected Semi-Arid Areas of Tanzania. 